Науковий вісник Чернівецького університету імені Юрія Федьковича: Історія. - № 1. - 2020.- С. 25-37 History Journal of Yuriy Fedkovych Chernivtsi National University. - № 1. - 2020. - pp. 25-38 DOI https: /doi.org/10.31861/hj2020.51.25-38 hj.chnu.edu.ua

УДК 94(477.83/.86) : $070 « 1898 / 1914 »$

() Андрій Королько* (Івано-Франківськ)

\title{
ДІЯЛЬНІСТЬ ЧИТАЛЬНІ І ФІЛІЇ ТОВАРИСТВА «ПРОСВІТА» У М. СНЯТИН НАПРИКІНЦІ XIX - НА ПОЧАТКУ XX СТ.
}

У статті досліджується діяльність читальні $і$ філії товариства «Просвіта» у м. Снятин наприкінияі XIX - на початку XX cm. Проаналізовано статути «Просвіти» щзодо організації діяльності філій і читалень культурно-просвітницького товариства. Охарактеризовано діяльність читальні та простежено форми роботи філї «Просвіти» у м. Снятин. Звертається увага на участь у роботі філї товариства відомого украӥнського письменника та громадського діяча Василя Стефаника.

Ключові слова: читальня, філія, «Просвіта», Покуття, культурно-просвітницька робота, бібліотека.

Andrii Korolko (Ivano-Frankivsk)

\section{ACTIVITIES OF THE READING ROOM AND AFFILIATE OF THE «PROSVITA» IN THE TOWN OF SNIATYN (LATE XIXTH - EARLY XXTH CENTURIES)}

Abstract. The statutes of «Prosvita» concerning organization of activity affiliates and reading rooms of the company are analyzed. Affiliates and reading rooms of «Prosvita» were to become centers of cultural revival for Ukranians of the Austro-Hungarian Empire.

In Sniatyn county there was the worst situation with the establishment of reading rooms of "Prosvita» in Pokuttia at late XIXth century. In the town of Sniatyn the reading room of "Prosvita" (it has 48 members) was opened only in 1898. In the first years the reading room community developed poorly due to the strong positions of the Ukrainian Radical Party and other Ukrainian cultural and educational associations of the town.

At early XXth century the work of the reading room of "Prosvita» in Sniatyn was intensified: evenings with dances were organized, a new choir was created and new performances were staged.

The foundation of the affiliate in 1909 became the apogee of practical activity of the reading rooms in Snyatyn county. There were three sections in the affiliate: reader; theater and concert; educational. In May 1912, the affiliate approved a program of educational work in Sniatyn county. Affiliate members checked the reading rooms, organized lectures, educational and economic conferences, courses, folk festivals, amateur performances and evenings. The library of the affiliate of «Prosvita» was established in Snyatyn.

In 1914 there were seven sections of the affiliate of «Prosvita»: reader; national holidays, folk festivals and amateur performances; "Renaissance» (educational); cooperative; publishing; combating illiteracy; anniversary. At the request of the affiliate, committees were set up in March 1914 in the villages of Sniatyn county to prepare the celebration of Taras Shevchenko's centenary. On May 10, 1914, of the affiliate of «Prosvita» in Sniatyn organized a county holiday to mark the occasion of T. Shevchenko's anniversary.

* .і.н., доцент кафедри історії України Прикарпатського національного університету імені Василя Стефаника.

$\mathrm{PhD}$ in History, Associate Professor, the Department of History of Ukraine, Vasyl Stefanyk Precarpathian National University.

orcid.org/0000-0001-7435-5806

E-mail: andrii.korolko@pnu.edu.ua 
Famous Ukrainian writer and public figure Vasyl Stefanyk took an active part in the work of the affiliate. He was a co-founder of the affiliate of company, worked on the promotion of cultural and educational work of «Prosvita».

Keywords: reading room, affiliate, «Prosvita», Pokuttia, cultural and educational work, library.

2018 року виповнилося 150 років від заснування громадської організації товариства «Просвіта», утвореної 8 грудня 1868 р. у м. Львові з метою культурного розвитку та піднесення національної свідомості українського народу. «Просвіта» поширила діяльність на всі українські землі. Створена в останній чверті XIX ст. організаційна структура на місцях (філія - читальні) підпорядковувалася головному осередку товариства у м. Львові. Саме на філії і читальні «Просвіти» в умовах політизації національного руху покладалася велика надія у культурному пробудженні українців АвстроУгорської імперії. В тогочасній українські газетній періодиці Східної Галичини детально подавалася інформація про діяльність осередків товариства «Просвіта», зокрема й у м. Снятин.

Метою статті є комплексне дослідження діяльності читальні і філії товариства «Просвіта» у м. Снятин наприкінці XIX - на початку XX ст. Ї̈̈ досягнення передбачає вирішення таких завдань: проаналізувати статути «Просвіти» щодо організації діяльності філій і читалень культурно-просвітницького товариства; охарактеризувати діяльність читальні товариства у м. Снятин; простежити форми роботи філії «Просвіти» у м. Снятин; звернути увагу на участь у роботі філії товариства відомого українського письменника та громадського діяча Василя Стефаника.

Ця проблема ще не стала предметом вивчення в історіографії. Окремі аспекти з досліджуваної проблеми знайшли своє відображення в наукових працях сучасних українських істориків I. Зуляка ${ }^{1}$, А. Середяк ${ }^{2}$ та автора статті ${ }^{3}$.

Важливим джерелом для вивчення проблеми є неопубліковані матеріали, які зберігаються у Центральному державному історичному архіві України у м. Львові. Нами опрацьовано окремі архівні справи фонду 348 «Товариство «Просвіта», м. Львів», зокрема листування, протоколи зборів, списки, звіти та різні документи про діяльність читальні і філії «Просвіти» у м. Снятин ${ }^{4}$.

Другий корпус використаних джерел - тогочасна українська газетна періодика Східної Галичини. «Діло», «Батьківщина», «Свобода», «Читальня. Письмо з Просвіти», «Ілюстрований калєндар товариства «Просвіта» приділяли значну увагу культурно-просвітницькому становищу народу в Східній Галичині. Часописи друкували звіти про діяльність товариства, представлені й обговорені на щорічних загальних зборах чи спеціальних нарадах. Вони ознайомлювали загал із даними про кількість членів філій і читалень, змінами керівного складу інституції, пропозиціями щодо корегування окремих статутних положень, із розвитком відносин з іншими українськими товариствами, заснуванням при читальнях крамниць і позичкових кас, видавничою діяльністю тощо. На сторінках тогочасних газет у рубриках «Новинки», «Всячина», «Письма $з$ краю», «Вісті $з$ краю», «Рух в руських товариствах», «Рух політичний, просвітний і економічний руського народу», «Просьвітний, економічний і політичний рух серед нашого народу», «Вісті з Товариства «Просвіта», «3 читальняного руху», «Дописи», «Сьвято Шашкевича», «3 ювілейних обходів у краї» в різних за змістом і за формою статтях подавалася інформація про культурно-просвітницьку роботу читальні і філії «Просвіта» У м. Снятин в кінці XIX - на початку XX ст. Загалом джерелознавча цінність тогочасних газетних публікацій полягає в тому, що тут вміщувалися доволі цінні інформативні матеріали 3 питань культурно-просвітницького та громадського життя краю, практичної праці осередків «Просвіти» на місцях.

Діяльність товариства «Просвіта» від часу заснування у 1868 р. до початку Першої світової війни регулювалася статутами 1868, 1873, 1876, 1891, 1906 рр. Головним завданням статуту 1891 р. стало поширення просвіти серед усіх верств українського населення краю. Для кристалізації організаційних форм роботи і посилення діяльності головного осередку «Просвіти» у м. Львові потрібно було відкривати нові філії і читальні товариства5. А тому перші читальні на власних статутах «Просвіта» почала закладати на початку 1890 -х рр. ${ }^{6}$. Згідно з новим статутом, автором якого був О. Колесса, читальні «Просвіти» за допомогою керівного осередку у м. Львові та філій на місцях мали створювати рільничо-господарські і промислово-торговельні спілки, щадничі і позичкові товариства, шпихліри (зерносховища) та крамниці, влаштовувати відкриті лекції, вечорниці, організо- 
вувати господарські і промислові виставки, навчати правильному веденню сільськогосподарських робіт, відкривати господарські і промислові школи․

Координуючим центром діяльності низки осередків «Просвіти» на місцях були філії, які розташовувались у повітових містах. Їм підпорядковувалася робота читалень товариства, які зосереджувались по селах і містечках краю. 24 січня 1894 р. керівництвом культурно-просвітницького товариства був прийнятий перший устав (статут) для читалень «Просвіти» ${ }^{8}$.

31896 р. головний осередок «Просвіти» у м. Львові запровадив люстрацію читалень, яку здійснював член керівного ядра товариства. В його обов'язки входили: перевірка стану читалень і сільських господарств; читання лекцій на господарську тематику тощо. Такі перевірки в середині 1890$\mathrm{x}$ рр. представник «Просвіти» провів і в Снятинському повіті9.

У 1908 р. головним осередком «Просвіти» у м. Львові підготовлені збірник правил (регулямін) та інструкція щодо діяльності філій товариства. Керівний осередок філії, передусім його голова, $\epsilon$ керманичем читалень «Просвіти» у своїй окрузі. У свою чергу, читальні товариства повинні бути вогнищем праці для просвіщення народних мас. Для організації і регулювання такої роботи мають створювати спеціальні читальняні комісії. Провідники читальняної роботи по селах краю зобов'язані звертати увагу на такі ділянки праці: загальнопросвітню, економічно-господарську і суспільно-правничу ${ }^{10}$.

Одразу треба визнати, що в Снятинському повіті склалася найгірша ситуація із заснуванням читалень «Просвіти» на Покутті в кінці XIX ст. На кінець 1896 р. Снятинщина виявилася єдиною серед 47 повітів Східної Галичини, де не було зареєстровано жодного осередку культурно-просвітницького товариства ${ }^{11}$. Представник головного осередку «Просвіти» у м. Львові Василь Король, здійснюючи протягом 20 вересня - 4 жовтня 1896 р. люстрацію громадського, господарського і культурно-просвітницького життя 10 громад Снятинського повіту (в селах Будилів, Орелець, Видинів, Вовчківці, Русів, Стецева, Карлів, Рожнів, Іллінці та в містах Снятин і Заболотів ${ }^{12}$, 3 сумом відзначав, що місцеві люди не знають про 28-річну діяльність культурно-просвітницького товариства. По селах краю у недільні і святкові дні «панує безлад, музика і гулятика, взаємна ненависть і завидність, самолюбство і захланність, п’янство, хрунівство, неморальність, особливо між молоддю». Тому через це й немає у Снятинському повіті жодної української читальні, крамниці, шпихліра, щадничо-позичкової каси, бо «немає підстави, немає здорової науки, а мабуть немає і людей розумних, щирих і до роботи охочих». Люстратор зауважив, що донедавна на Снятинщині було більше двадцяти «самостійних» читалень, але з них зараз існує ледве дві або три, і то без жодної економічної організації. Просвітницько-економічну роботу ведуть тільки поодинокі люди. Як приклад, В. Король навів активну працю селянина з с. Орельця Тимофія Равлюка, який вміло обробляє 10 моргів землі, а своїх двох синів відправив на навчання до гімназійних шкіл: «Коби то Снятинщина хоч сотки таких Равлюків мала (а могла б їх тисячі мати), тоді певно могла б вона бути взірцем і прикладом для інших повітів» ${ }^{13}$.

В одному із дописів часопису «Діло» в серпні 1897 р. саркастично зазначалося, що по всій Русі-Україні лунають пророчі слова Т. Шевченка «Руська дума, руська пісня не вмре, не загине», тільки в м. Снятин, де майже все населення руське (українське), ба навіть римо-католики і євреї вдома говорять по-українськи, не довіряють тій пісні, чи не хочуть їі чути. Донедавна в Снятині відбулися вечорниці, але в залі була пустка: «Така апатія до свого у непросвічених народів в Азії або в Африці себе оправдала б, але не в ученому Снятині» ${ }^{14}$. На жаль, осередок «Просвіти» у м. Снятин належним чином не підтримав урочистий захід у травні 1898 р., присвячений 50-річчю скасування панщини в Галичині і організований українськими товариствами краю ${ }^{15}$. Дописувач газети «Діло», прізвище якого ховається під псевдонімом «Вичоса», прикро констатував, що на концерт, приурочений з нагоди такої події у м. Снятин, прийшла тільки одна-однісінька українська вчителька та два греко-католицькі священники: «Інші воліли сидіти вдома і не показуватися та, як звичайно на руських (українських) народних торжествах в Снятині, світити неприсутністю, бо їм з тим добре i вигідно нічого не робити, селянами не інтересуватися, лише благоденствувати» ${ }^{16}$.

У свою чергу, один із лідерів українського радикального руху Кирило Трильовський, який довгий час проживав на Снятинщині і був активним учасником громадського життя краю, виступив проти закидів тогочасної національно-демократичної преси Галичини про відсутність осередків 
українського культурно-просвітницького життя Снятинського повіту. Він наголосив, що на середину 1898 р. на теренах Снятинщини функціонує 11 читалень, заснованих на давніх статутах, виданих головним осередком «Просвіти» у м. Львові, і 7 читалень, сформованих на статутах економічно-просвітницького «Коломийського товариства «Народних спілок». У м. Снятин працює радикальне міщанське просвітне товариство «Наука». К. Трильовський підсумував: «Зваживши, що Снятиньский повіт числить 41 громад, побачимо, що справа просвіти стоить тут цїлком не зле» ${ }^{17}$.

Станом на кінець 1899 р. серед 41 громади повіту функціонувало лише чотири читальні зі 194 членами, планувалося відкрити ще три осередки «Просвіти» ${ }^{18}$. Проте в цей самий час на Снятинщині функціонувало 22 осередки економічно-просвітницького «Коломийського товариства «Народних спілок», які були у фарватері впливу українських радикалів під орудою К. Трильовського ${ }^{19}$. Зауважимо, що станом на 1901 р. на території Покуття функціонувало 48 осередків цього товариства, з них більша частина - 29 - розташовувалася у Снятинському повіті ${ }^{20}$.

Читальня «Просвіти» у м. Снятин була відкрита в 1898 р. Перші ії загальні збори відбулися 30 жовтня 1898 р., а записалося 48 членів [9, арк. 3, 3 зв.]. До керівного осередку читальні увійшли: о. М. Гриньовський (голова), А. Савкевич (заступник голови), І. Зіньковський (скарбник), І. Калитчук (бібліотекар), Т. Томей (секретар) ${ }^{21}$. За перший рік діяльності снятинська читальня «Просвіти» мала 69 членів, 88 книг у бібліотеці, виписувала часописи «Діло», «Господар», «Літературно-науковий вісник» ${ }^{22}$.

Стан іiі діяльності в перші три роки виявився жалюгідним через сильні позиції в місті представників Української радикальної партії (під орудою радикалів у місті функціонувало культурно-просвітницьке товариство «Наука» ${ }^{23}$, яке 9 лютого 1896 р. Снятин організувало у м. Шевченківські вечорниці $\left.{ }^{24}\right)$ та активної роботи інших українських культурно-просвітницьких осередків міста - Руської (Української) міщанської читальні і «Руської Бесіди» 25 . До речі, голова осередку «Руської Бесіди» у м. Снятин Михайло Крикливець (до нього приєднався і Кирило Трильовський ${ }^{26}$ ) у листі від 5 вересня 1900 р. скаржився керівництву «Просвіти» у м. Львові через те, що о. Микола Гриньовський відібрав приміщення для роботи міської читальні «Просвіти» і не хотів повернути назад у власність аматорського театрального товариства ${ }^{27}$. Це стало основною причиною переобрання керівництва читальні «Просвіти». Новим її головою у жовтні 1900 р. обрано Антонія Савкевича, його заступником - Стефана Ляшкевича, а секретарем - Миколу Дутчака ${ }^{28}$. У перші місяці своєї діяльності читальня «Просвіти» зазнала цькувань і від Руської міщанської читальні. Керівництво осередку «Просвіти» у листі до редакції українського часопису «Свобода» від 19 березня 1900 р. відкинула звинувачення з боку членів Руської міщанської читальні про те, що нібито просвітяни належним чином не вшанували під час поминального богослужіння фундатора їхнього культурно-просвітницького осередку Теофіла Кобринського 3 нагоди 20-річчя його смерті ${ }^{29}$. Конфліктна ситуація між двома культурно-просвітницькими осередками мала своє продовження і наступного 1901 р. До речі, керівництво читальні «Просвіти» у м. Снятин назвало Руську міщанську читальню «кацапсько-радикальною», якою орудує о. Филимон Огоновський ${ }^{30}$.

У листопаді 1900 р. на загальних зборах був обраний новий керівний склад читальні на чолі 3 о. А. Сімовичем ${ }^{31}$. За сприяння останнього осередок товариства проводив доволі активну культурно-просвітницьку роботу. Зокрема, о. В. Сімович у перші місяці своєї праці організував вечорниці 3 танцями, сформував новий хор, підготував вистави: мелодраму «Підгоряни», комедії «Свекруха» Л. Лопатинського (вперше поставлена на сцені 24 лютого 1901 p. ${ }^{32}$, а 10 березня 1901 р. представлена в м. Городенка - «ця взаємна артистична прогулька вплинула дуже корисно на розвій духовного життя і взагалі дружніх зносин між міщанством і селянством обох повітів» ${ }^{33}$, «Наталка-Полтавка» I. Котляревського (вперше представлена на сцені 3 лютого 1901 р.) і «Сватання на Гончарівці» Г. Квітки-Основ'яненка ${ }^{34}$. В кінці 1900 р. запроваджено читання лекцій для селян на кооперативні теми: «Про садівництво» (16 грудня), «Про пасічництво» (22 грудня), «Про вживання овочів» (30 грудня), «Про жіноче господарство» та «Початки і розвій міщанського стану» (заплановані виступи просвітян на початку 1901 р.). Планувалося будівництво приміщення для читальні товариства ${ }^{35}$.

Проте і о. А. Сімович не затримався довго. Новим головою читальні «Просвіти» в 1901 р. обрано Миколу Дутчака ${ }^{36}$.

На жаль, у проміжку часу між 1902-1914 рр. нами поки що не виявлено жодних архівних свідчень і даних тогочасної газетної періодики про діяльність читальні «Просвіти» у м. Снятин. 
Звичайно, вона продовжувала функціонувати, виконувала різноманітні ділянки просвітницького і мистецького змісту. Але те, що в кінці XIX - на початку XX ст., згідно з документальними матеріалами, спостерігаємо суперечки між українськими культурно-просвітницькими товариствами міста, залишається доконаним фактом. Це, у свою чергу, стало чи не визначальним у тому, що серед усіх повітів Східної Галичини філія «Просвіти» в Снятинському була заснована найпізніше, в 1909 р.

Перші загальні збори новоствореної філії «Просвіти» відбулися 5 вересня 1909 р. у с. Потічок Снятинського повіту ${ }^{37}$, а перші організаційні збори - 18 вересня 1909 р. у м. Снятин ${ }^{38}$. Його членами-засновниками стали: Семен Зінкевич (голова), Володимир Палятинський (заступник голови), Лесь Бордун (секретар), Петро Сандуляк (касир), Михайло Якимець (бібліотекар), Іван Фодчук (контролер), Іван Сандуляк («виділовий»), Василь Стефаник, Дмитро Рошка, Василь Проданюк (усі заступники). До складу філії записалося понад 60 членів ${ }^{39}$.

Головний осередок товариства у листі від 25 вересня 1909 р. оригінально привітав заснування осередку: «Щирим серцем та желанями найкрасшого розвитку витає Гол. Видїл наймолодшу свою філїю Снятиньску» ${ }^{40}$ (у Снятинському повіті дійсно серед усіх повітів Східної Галичини філія «Просвіти» була заснована останньою. - A. K.). Цікаво, що майже одночасно в кінці літа - восени 1909 р. були засновані три нові читальні «Просвіти» в с. Устя, с. Красноставці і с. Попельники Снятинського повіту ${ }^{41}$.

Зауважимо, що Семен Зінкевич обіймав посаду голови філії «Просвіти» більше двох років. 2 листопада 1911 р. обраний новий керівний склад філії «Просвіти»: голова - управитель школи в с. Вовчківці Василь Равлюк (був незмінним керівником Снятинської «Просвіти» більше тридцяти років); заступник голови - управитель школи в с. Трійця Йосиф Нагорський (за іншими документальними свідченнями - залізничний урядник Андрій Романчак ${ }^{42}$ ); секретар - учитель народної школи в с. Любківці Олекса Гавдуник; касир - житель м. Снятина Михайло Якимець; контролер - студент права з с. Устя Василь Порайко; «виділові» - селянин із с. Вовчківці Василь Тимчук, учитель із с. Карлів (нині с. Прутівка Снятинського району Івано-Франківської обл.) Антін Онищук, учитель 3 м. Заболотів Володимир Синятович, учитель із с. Тростянець Йосиф Михайлецький43. При головному осередку «Просвіти» Снятинського повіту функціонували три секції: «відчитова» (відповідальні В. Порайко, А. Онищук, С. Фодчук); театрально-концертова (А. Онищук, Й. Нагорський, М. Ломацький); освітня («комісия Рідної школи») (В. Равлюк, А. Онищук, С. Гайчук) $)^{44}$. На початковому етапі свого існування канцелярія Снятинської філії «Просвіти» містилися у с. Вовчківці ${ }^{45}$. Засідання протягом 1909-1914 pр. періодично (до одинадцяти-дванадцяти в році) проводилися У м. Снятин, м. Заболотів, с. Вовчківці і с. Устя.

На одному із засідань філії «Просвіти» від 2 грудня 1911 р. було визначено, за якими населеними пунктами просвітяни філії будуть здійснювати нагляд за роботою читалень товариства: А. Онищук мав контролювати діяльність осередків «Просвіти» у с. Карлів, с. Видинів і с. Залуччя; В. Порайко у с. Будилів, с. Устя, с. Орелець, с. Тулова, с. Вовчківці, с. Любківці, с. Альбінівка (нині с. Шевченкове Снятинського району Івано-Франківської обл.), с. Ганьківці і с. Задубрівці; С. Фодчук у с. Русів і с. Потічок; І. Воєвідка в с. Підвисока; М. Ломацький в с. Княже, с. Попельники, с. Джурів, с. Новоселиця, с. Рожнів (нині село Косівського району Івано-Франківської обл.), с. Іллінці, с. Тростянець; Й. Нагорський у с. Трійця, с. Борщів і с. Хлібичин; В. Синятович в с. Демиче (нині входить до складу смт Заболотів Снятинського району) і м. Заболотів; О. Гавдуник в с. Олешків і с. Тулуків ${ }^{46}$. У лютому 1913 р. оновлено склад членів філії «Просвіти», які допомагали роботі читалень краю: учитель з с. Орелець Семен Фодчук відав роботою читалень в с. Любківці та с. Задубрівці; учитель з с. Любківці Олекса Гавдуник мав перебувати в с. Олешків; управитель школи в с. Вовчківці Василь Равлюк відповідав за роботу читалень в рідному селі і с. Орелець; управитель школи с. Карлів Іван Голубович мав перебувати в с. Карлів і с. Тулова; учитель з с. Карлів Антін Онищук курував читальнями в с. Драгасимів і с. Залуччя; учитель з с. Устя Теодор Мервяк був відправлений до читальні в с. Белелуя; адвокат з м. Снятина Іван Семанюк (Марко Черемшина) відповідав за роботу осередків товариства в с. Красноставці та с. Русів; професор реальної школи Іван Ідуля з м. Снятина орудував просвітницькою роботою в рідному місті і в с. Потічок; учитель 3 с. Драгасимів Іван Палійчук відповідав за роботу читалень в с. Княже і с. Попельники; учитель 3 с. Новоселиця Михайло Ломацький мав контролювати діяльність осередків у с. Трійця і с. Тростянець; директор кооперативного товариства «Народна каса» в м. Заболотів Іван Павлюк орудував 
читальнями в с. Рожнів і с. Новоселиця; суддя в м. Заболотів Ромуальд Думін делегований до с. Тулуків; начальник податкового уряду в м. Заболотів Ізидор Пісецький відповідав за роботу читальні в с. Келихів. Оскільки М. Ломацький переїхав на нове місце роботи в Косівському повіті, то на його місце заступив учитель Антін Кококрудз, який також відповідав за роботу трьох читалень у с. Рожнів ${ }^{47}$.

У травні 1912 р. філією була прийнята програма просвітньої праці в Снятинському повіті. В ній вказувалося, що місцеве населення бажає освіти, але для цього не вистачає проводу. Оживити роботу читалень повинна інтелігенція своєю систематичною і невсипущою працею. Тому на членів Снятинської філії було покладено обов'язок вести люстрації (перевірки) читалень краю, збирати матеріали за допомогою «квестіонарів» (питальників). Сама ж просвітницька праця має вестися за допомогою: відчитів і викладів (лекцій); просвітньо-економічних конференцій; курсів; народних свят; аматорських вистав; фестин ${ }^{48}$.

Щодо першої ділянки роботи, то виступи просвітян мають охопити «красне письменство, історію (до речі, А. Онищук на засіданні філії «Просвіти» 19 лютого 1913 р. для цього просив закупити 20 примірників «Історії України» М. Аркаса та оголосити конкурс серед членів читалень на знання національної історії ${ }^{49}$ ) і географію, господарство, шкідливість алькоголю, якої нам треба школи». Після першого року подання відчитів слухачі мають засвоїти прості твори української літератури, у них має пробудитись любов до книжки. Слухачі мають бути підготовленими до самостійного читання, прийнявши тему відчитів 3 красного письменства, укладеного членом філії «Просвіти» Іваном Голубовичем ${ }^{50}$.

Перед підготовкою проведення відчиту член філії повинен повідомити голову читальні про необхідність зібрати якнайбільше членів культурно-просвітницького осередку для проведення такого заходу. Після заслуханого відчиту члени читальні мають брати участь у дискусії. Делегат після цього повинен підготувати звіт з проведеного заходу і надіслати матеріал до філії товариства (на кінець 1912 р. такі звіти («квестіонари») надіслали читальні «Просвіти» сіл Красноставці, Драгагасимів, Рожнів, Вовчківці, Тростянець, Устя, Видинів, Стецева, Потічок, Тулова, Карлів і міста Снятин ${ }^{51}$ ). Оскільки у Снятинському повіті значиться мале число інтелігенції, то такі відчити можуть відбуватися не один раз, а двічі на тиждень ${ }^{52}$. Кожен відчит редагував Антін Онищук. Після кожних трьох виступів з української літератури кожен четвертий мав бути присвячений історії України, географії чи господарству. Загалом у 1912 р. члени філії «Просвіти» та активні громадські діячі в різних населених пунктах Снятинщини виступили з такою кількістю відчитів: Антін Онищук - 27, Василь Порайко - 10, Олекса Гавдуник і Михайло Ломацький - по 5, Іван Палійчук та Іван Голубович - по 4, Семен Фодчук, Василь Равлюк, Йосиф Нагорський, Ос. Корчинський (студент університету) - по 3, Іван Маєвський, Є. Захаркевичева та В. Фроляк - по $2^{53}$. За активну культурно-просвітницьку роботу 22 грудня 1912 р. до складу філії «Просвіти» кооптовано нових членів: від Заболотівського судового округу секретаря суду Ромуальда Думіна, управителя податкового уряду Ізидора Пісецького, учительку Марію Слюзарівну, управителя школи в с. Новоселиця Михайла Ломацького; від Снятинського судового округу професора реальної школи Івана Гдулю, управителя школи Олексу Гавдуника, учителя Івана Маєвського ${ }^{54} .16$ квітня 1913 р. відпоручників секції Українського студентського союзу у м. Снятин студента філософського факультету Володимира Палятинського i студента-правника з с. Устя Августина Задуровича включили до філії «Просвіти» ${ }^{55}$.

Щодо просвітніх конференцій, то вони мали скликатися у такій черговості населених пунктів краю: с. Вовчківці, м. Снятин, с. Карлів, с. Попельники, с. Тулуків, с. Рожнів, с. Підвисоке і м. Заболотів. На конференції необхідно запрошувати не тільки місцевих просвітян, але й із сусідніх громад. Серед присутніх мають обов'язково бути діти, щоби «виросли на хосенних членів укр. суспільности» $\rangle^{56}$.

Філією «Просвіти» ухвалено, що з початком 1913 р. спільно з філією «Сільського господаря» будуть влаштовуватися чотири господарські і один просвітній курси. Перший господарський курс годівлі свиней вестфальської породи і кролів різних порід мав відбутися у с. Тулова, оскільки там були зразковий хлів і кролярня; другий - господарсько-пасічницький у с. Вовчківці; третій - «Як будувати і уладити стайню» в с. Княже (у цьому селі розташовувалася новозбудована зразкова стайня осередку товариства «Сільський господар»); четвертий - щодо правильного ведення господарсько-торговельних спілок у м. Снятин. Просвітній курс мав відбутися у Снятині і в ньому 
були визначені такі теми виступів: «Як вести аматорські кружки», «Як читати і деклямувати», «Як устроювати народні свята», «Як устроювати народні фестини», «Як збирати на народні ціли», «Як вести кружок забавовий». Після просвітнього курсу відбудеться друга частина - «вечерок», на якому будуть заслухані відчити, поетичні декламації і монологи, співатиме хор і гратиме оркестр, «товариська забава» і одноактна аматорська вистава. Щоправда, вечірня частина програми просвітнього курсу була платною, зібрані кошти з вечора мали б піти на закупівлю книжок для учасників курсів ${ }^{57}$.

У четвертій ділянці культурно-просвітницької праці філія «Просвіти» вимагала, щоб кожна читальня проводила такі «народні свята»: урочистості з нагоди вшанування Тараса Шевченка (до кінця травня) та Івана Франка (осінь), скасування панщини в Галичині («Свято свободи»). На ці свята головний осередок товариства Снятинського повіту мав відправляти своїх відпоручників ${ }^{58}$. До речі, філія «Просвіти» 19 жовтня 1913 р. організувала святкове засідання з нагоди 40-літнього ювілею творчості I. Франка, на яке були запрошені депутати австрійського парламенту і Галицького крайового сейму, делегат головного осередку «Просвіти» Ярослав Весоловський, учительство краю, студентська і гімназійна молодь, представники всіх повітових товариств, читалень «Просвіти», осередків «Січі», жіночих громад, члени «Снятинського Бояна», «Бесіди» 3 м. Заболотова та старшина окружного осередку пожежно-руханкового товариства «Січ» у м. Заболотів ${ }^{59} .27$ вересня 1913 р. було прийнято рішення про призначення одноразової річної стипендії імені І. Франка в сумі 100 корон (голова філії В. Равлюк одразу ж передав 50 корон до стипендійного фонду) для обдарованої молоді та закупівлі повного зібрання творів українського письменника ${ }^{60}$.

Філія «Просвіти» вітала роботу тих читалень, які організовують аматорські вистави та фестини у селі, і просила, щоб в організації таких розважальних заходів їм допомагали інші товариства краю ${ }^{61}$.

У травні 1912 р. було прийнято рішення про заснування повітової бібліотеки філії «Просвіти» у м. Снятин ${ }^{62}$. В кінці 1912 р. було визначено відповідальних членів за ведення конкретної ділянки роботи філії «Просвіти»: адміністративні справи вів ії голова Василь Равлюк; бібліотечна справа перебувала під орудою Івана Голубовича; діяльність аматорських гуртків курував Михайло Ломацький; організацією проведення «обходів» і фестин займався Іван Маєвський; підготовка жіноцтва до культурно-просвітницької роботи перебувала в полі зору Марії Слюзарівної; діяльність кас, склепів (крамниць) і молочарень залишалися під орудою Івана Павлюка і Олекси Гавдуника; організацію викладів 3 «чарівною ліхтарнею» та відчитів було покладено на руки Антіна Онищука (в кінці 1913 р. цю ділянку роботи доручено виконувати учителю Івану Палійчуку혀); включення нових членів до лав головного осередку товариства «Просвіта» входило в обов'язки Ромуальда Думіна та Ізидора Пісецького; загальна бухгалтерія філії перебувала в руках Семена Фодчука ${ }^{64}$.

Напередодні Першої світової війни в 1914 р. діяло сім секцій філії «Просвіти»: читальняна (І. Голубович); народних свят, фестин і аматорських вистав (І. Дутчук); «Відродження» (освітня) (о. В. Залуцький); кооперативна (О. Гавдуник); видавнича (І. Палійчук); боротьби з неграмотністю (В. Порайко) (хоча ця секція, фактично, належним чином не функціонувала лише 3 тої причини, як зауважив В. Равлюк у листі від 24 травня 1912 р., що у Снятинському повіті всі діти письменні, оскільки «...народ посилає радо діти до школи і вся молодша генерация є грамотна» $\left.{ }^{65}\right)$; ювілейна (3 нагоди підготовки до сторіччя від дня народження Т. Шевченка) (Т. Мервяк ${ }^{66}$. На заклик ювілейної секції філії «Просвіти» у березні 1914 р. в 29 селах Снятинського повіту були засновані комітети для підготовки святкування сторіччя від дня народження Кобзаря ${ }^{67} .10$ травня 1914 р. філія «Просвіти» у м. Снятин організувала повітове свято з нагоди ювілею Т. Шевченка ${ }^{68}$.

Долучався до організації роботи філії і читалень «Просвіти» у м. Снятин найвідоміший його земляк, український письменник, депутат австрійського парламенту Василь Стефаник. У кінці 1890х pp. він був секретарем читальні товариства в с. Русів Снятинського повіту ${ }^{69}$. Письменник взяв участь у перших загальних зборах філії 19 вересня 1909 р., які відбулися у приміщенні міщанської читальні у м. Снятин. В. Стефаник доповнив виступ В. Палятинського про значення філії «Просвіти» в організації культурно-просвітницької праці у Снятинському повіті. До речі, на цих зборах осередок товариства був поділений на три секції: організаційну, наукову і економічну. До його складу ввійшло 60 нових членів ${ }^{70} .8$ грудня 1912 р. український письменник взяв участь у загальних зборах філії «Просвіти», де були підбиті підсумки за календарний рік та прийняті нові важливі рішення 
щодо перспектив подальшої праці головного осередку повіту ${ }^{71}$. Також Василь Стефаник долучився до роботи надзвичайних загальних зборів філії, які відбулися 9 березня 1913 р. у м. Снятин ${ }^{72}$.

Напередодні Першої світової війни у Снятині поряд з філією «Просвіти» працювала її читальня, «Шкільна поміч», театральне товариство «Руська Бесіда», музичне товариство «Боян», кредитне товариство «Прут», кооперативний склад «Народної торгівлі ${ }^{73}$.

Отже, «Просвіта» була важливим чинником консолідації галицьких українців. Практична робота місцевих осередків товариства висвітлювалася в тогочасній українській газетній періодиці Східної Галичини та збережена у відповідних архівних матеріалах. На місцях важливим елементом піднесення національної самосвідомості українців було створення драматичних гуртків, оркестрів, бібліотек, крамниць і позичкових кас, які стали не тільки центрами культурно-просвітницького та економічного життя, але й були осередками антиалкогольної боротьби, піднесення інтелектуального рівня населення міста Снятин, загалом краю. Ініціаторами створення таких осередків «Просвіти» стали місцеві греко-католицькі священники, вчителі, селяни. Перші кроки діяльності читальні «Просвіти» у м. Снятин виявилося непростими. На заваді якісного розвиту осередку «Просвіти» стояли інші українські культурно-просвітницькі товариства міста («Руська Бесіда», Руська (Українська) міщанська читальня, «Народна спілка», «Наука» та ін.), які перебували в руках місцевих радикалів та москвофілів. Проте з появою філії «Просвіти» в 1909 р. культурно-просвітницьке життя у м. Снятин та в населених пунктах Снятинського повіту набуло нових організаційних форм та стрункості розвитку. Долучився до розбудови Снятинської філії «Просвіти» іiї найвідоміший земляк, відомий український письменник-новеліст, громадський діяч, депутат австрійського парламенту Василь Стефаник. Будучи фактично співзасновником філії товариства, він неодноразово брав участь у іiі роботі, працював над піднесенням культурно-просвітницької розбудови організації.

Таким чином, потребує ретельного вивчення не тільки діяльність філії і читальні «Просвіти» у м. Снятин, але й всіх осередків товариства на Снятинщині. Зокрема, слабо дослідженими є практична робота читалень краю, їх культурно-просвітницька і соціально-економічна праця, відносини 3 місцевою владою, представниками радикального і русофільського (москвофільського) таборів. Доцільно матеріали тогочасної української газетної періодики зіставити з архівними матеріалами ф. 348 «Товариство «Просвіта», м. Львів» (звіти філій і читалень, листування їх з головним осередком товариства у м. Львові) і ф. 146 «Галицьке намісництво, м. Львів» (інформація про реєстрацію філій і читалень «Просвіти») Центрального державного історичного архіву України у м. Львові, а також з поодинокими документами Державного архіву Івано-Франківської області, для об’єктивного і ретельнішого дослідження діяльності осередків товариства на Снятинщині в кінці XIX - на початку XX ст.

1 І. Зуляк, Роль «Просвіти» у поширенні економічних знань у Східній Галичині (кінець ХІХ- початок $X X \mathrm{~cm}$.) [The role of «Prosvita» in disseminating economic knowledge in Eastern Galicia (late XIXth - early XXth centuries)], in «Україна: культурна спадщина, національна свідомість, державність», Львів, 2010, вип. 19, c. $151-160$.

2 А. Середяк, Діяльність товариства «Просвіта» в 1868-1914 рр. [The activities of «Prosvita» in 18681914], in «Нарис історії «Просвіти», Краків, Париж, Львів, 1993, с. 18-42.

3 А. Королько, Статути «Просвіти»-головний чинник організації діяльності філій $і$ читалень українських культурно-просвітніх товариств в Галичині (остання третина XIX- початок XX cm.) [Statues of «Prosvita» - the main factor in organizing the activties of affiliates and reading rooms of Ukrainian cultural and associations in Galicia (last third XIXth - early XXth centuries)], in «Калуські історичні студії», т. 3. Збірник наукових статей, документів і матеріалів, присвячений 150-річчю створення товариства «Просвіта, Івано-Франківськ, 2019, с. 29-41; А. Королько, Діяльність осередків товариства «Просвіта» на Покутті наприкінці XIX-початку XX cm. (за матеріалами часопису "Діло») [Activity of cells of «Prosvita» in Pokuttia at the late XIXth - early XXth centuries (based on «Dilo» newspaper)], in «Покуття - колиска українського національного державотворення», Івано-Франківськ, 2018, с. 237-266.

4 Центральний державний історичний архів України, м. Львів (далі - ЦДІАЛ України), ф. 348 Товариство «Просвіта», м. Львів, оп. 1, спр. 5118 Матеріали про діяльність філіалу товариства в містечку Снятин та репресії з боку окупаційних органів (Статистичні відомості, інформації, розпорядження і інші). 19091938 рр., 9 арк.; ЦДІАЛ України, ф. 348, оп. 1, спр. 5119 Протоколи зборів і засідань членів філіалу в Снятині (орихінали і копії). 1909-1938 рр., 296 арк.; ЦДІАЛ України, ф. 348, оп. 1, спр. 5120 Листування з філіалом 
в Снятині про заснування нових читалень, проведення загальних зборів, сплату членських внесків та інші організаційні питання. 1909-1926 рр., 248 арк.; ЦДІАЛ України, ф. 348, оп. 1, спр. 5122 Звіти про діяльність філіалу в Снятині. 1909-1938 рр., 92 арк.; ф. 348, оп. 1, спр. 5131 Протоколи зборів, списки, звіти та інші документи про діяльність читальні в Снятині-місто. 1898-1939 рр., 134 арк.

5 Новый статут Товариства «Просвъта» [The new charter of «Prosvita»], in «Батькоิвщина», 1891, 22 марта (3 цвьтня), ч. 12, с. 72.

6 Сорок лїт дїяльности «Просьвіти» [Forty years of activity of the «Prosvita»], in «Дїло», 1908, 8 грудня (25 падолиста), ч. 276, с. 1-2.

7 Загальнй Зборы товар. Просвъта. (Конещь) [General meeting of «Prosvita». (The end)], in «Дьло», 1890, 13 (25) серпня, ч. 182, с. 1.

8 Першій уставъ для Читалень «Просвъты» ухваленый Головнымъ Выдъломъ товариства «Просвътта» у Львовъ дня $24 \mathrm{н.} \mathrm{cm}$. съьня 1894 р. [The first charter for reading rooms of «Prosvita» of the approved by the headquarters in Lviv of January 24, 1894], in «Дьло», 1894, 19 (31) січня, ч. 14, с. 1-2.

9 Сорок лїт дїяльности «Просьвіти», с. 2.

10 Регулямін і інструкиия для видїлу філї̈ «Просьвіти» [Rules and instructions for affiliate management of «Prosvita»], in «Дїло», 1908, 5 червня (23 мая), с. 124, с. 2-3.

11 Справозданє зъ люстрачіи читалень и господарствъ селянскихъ, переведенои люстраторомъ «Просвътыл» въ повътьъ снятиньскоммъ [въ часъ вордъ 20 вересня до 4 жовтня 1896] [Report from of the lustration of the readings and peasant farms in Snyatyn County (September 20 - October, 1896)], in «Дьло», 1896, 11 (23) грудня, ч. 277, с. 1; Філіи и читальнґ «Просвътыл» [Affiliates and reading rooms of «Prosvita»], in «ДҺло», 1897, 5 (17) липня, ч. 150 , с. 3.

12 Справозданє Товариства «Просвъта» зъ руху просвътно-економічного въ р. 1896. Люстраціи Читалень «Просвътыл» и господарскихъ селяньскихъ [Report of «Prosvita» on the educational and economic movement in 1896. Lustration reading rooms of «Prosvita» and peasant farms], in «Свобода. Письмо політичне, просвњтне и господарске для народу», 1897, 13 (25) марта, ч. 11, с. 85.

13 Справозданє зъ люстраціи читалень и господарствъ селянскихъ, переведенои люстраторомъ «Просвътыл» въ повътьъ снятиньскоิмъ, с.1-2.

14 Вечерницъ безъ публики. Зъ Снятина пимуть намъ ... [Festiv evening without public. Write to us from the town of Snyatyn], in «Дьло», 1897, 8 (20) серпня, ч. 178, с. 1.

15 Дальше святкованє народного ювилею. Въ снятиньскомиъ повътьъ [Celebrating people’s anniversary. In Sniatyn county], in «Свобода. Письмо політичне, просвьтне и господарске для народу», 1898, 21 мая (2 червня), ч. 21, с. 164; Ювилей знесеня панщины и народного вордродженя галицкои Руси [Anniversary of the abolition of bonhold and the national revival of Galician Rus], in «Свобода. Письмо політичне, просвътне и господарске для народу», 1898, 7 (19) мая, ч. 19, с. 149.

16 Вычоса. Зъ Снятина пишуть нам ... [Vychosa. Write to us from the town of Snyatyn], in «Дьло», 1898, 11 (23) мая, ч. 103, с. 2.

17 К. [ирило] Т. [рильовський], Зъ Снятиньского [From Snyatynsky], in «Свобода. Письмо політичне, просвђтне и господарске для народу», 1898, 4 серпня (23 липня), ч. 30, с. 238.

18 Справозданє Народного Комітету. (Дальще) [Report of the People's Committee (Continuation)], in «Дьло», 1900, 7 (20) липня, ч. 151, с. 2.

19 Безсторонний, Зъ Снятиньского [From Snyatynsky], in «Свобода. Письмо політичне, просвьтне и господарске для народу», 1899, 7 (23) сьчня, ч. 3, с. 20.

20 Закладайте «Народні Спілки»! [Establish «People’s Unions»!], in «Запорожець. Калєндар на переступний рік 1904», Коломия, 1904, с. 115; А. Королько, «Коломийське товариство Народних Спілок»: ідеологічні засади і практична діяльність ї̈ осередків на Покутті (кінецьь XIX-початок XX cm.) [«Kolomyia society of People's Unions»: ideological principles and practice of its branches in Pokuttia (late XIXth - early XXth centuries)], in «Питання історії України», Чернівці, Технодрук, 2014, т. 17, с. 68-82. А. Королько, «Народні спілки» на Снятинщині в кінці XIX - на початку XX ст. [«People’s Unions» in Snyatyn region (late XIXth - early XXth centuries)], in «Снятин. Краєзнавчий і літературно-мистецький журнал», 2016, ч. 15(29), c. $62-77$.

21 ЦДІАЛ України, ф. 348, оп. 1, спр. 5131 Протоколи зборів, списки, звіти та інші документи про діяльність читальні в Снятині-місто. $1898-1939$ рр., арк. 4; 3о Снятина пишуть намъ ... [From the town of Snyatyn to write], in «Дъло», 1898, 30 жовтня (11 падолиста), с. 2.

22 ЦДІАЛ України, ф. 348, оп. 1, спр. 5131 Протоколи зборів, списки, звіти та інші документи про діяльність читальні в Снятині-місто. 1898-1939 рр., арк. 16.

23 3ъ Снятина пишуть намъ: Дня 27 н. ст. жовтня воิдбули ся въ Снятинг першиิ загальнй зборы повгттового товариства «Наука» [From the town of Snyatyn to write: The first general meeting of the county society «Science» took place in Snyatyn on October 27], in «Дьло», 23 жовтня (4 падолиста), ч. 238, с. 3. 
24 Дня 9 лютого с. р. вордули ся въ Снятинъ вечерницฺъ въ честь Тараса Шевченка устроєнй товариством «Наука»... [A celebratory evening in honor of Taras Shevchenko took place in Snyatyn on February 9 , organized by the society «Science»], in «Дьло», 1896, 19 лютого (2 марта), ч. 38, с. 3.

25 3ъ Снятина пишуть намъ: "Наша дума, наша пғсня не вмре, не загине, и оживе добра слава, слава Украины» ... [From the town of Snyatyn to write: «Our word, our song, will not die, will not perish, and the good, glory of Ukraine will come to life»], in «Дьло», 1896, 10 (22) серпня, ч. 179, с. 3.

26 ЦДІАЛ України, ф. 348, оп. 1, спр. 5131 Протоколи зборів, списки, звіти та інші документи про діяльність читальні в Снятині-місто. 1898-1939 рр., арк. 25, 25 зв.

27 ЦДІАЛ України, ф. 348, оп. 1, спр. 5131 Протоколи зборів, списки, звіти та інші документи про діяльність читальні в Снятині-місто. 1898-1939 рр., арк. 11, 11 зв., 20.

28 ЦДІАЛ України, ф. 348, оп. 1, спр. 5131 Протоколи зборів, списки, звіти та інші документи про діяльність читальні в Снятині-місто. 1898-1939 рр., арк. 21 зв.

29 ЦДІАЛ України, ф. 348, оп. 1, спр. 5131 Протоколи зборів, списки, звіти та інші документи про діяльність читальні в Снятині-місто. 1898-1939 рр., арк. 19, 19 зв.

30 ЦДІАЛ України, ф. 348, оп. 1, спр. 5131 Протоколи зборів, списки, звіти та інші документи про діяльність читальні в Снятині-місто. 1898-1939 рр., арк. 38, 38 зв., 39.

31 ЦДІАЛ України, ф. 348, оп. 1, спр. 5131 Протоколи зборів, списки, звіти та інші документи про діяльність читальні в Снятині-місто. 1898-1939 рр., арк. 28.

32 ЦДІАЛ України, ф. 348, оп. 1, спр. 5131 Протоколи зборів, списки, звіти та інші документи про діяльність читальні в Снятині-місто. 1898-1939 рр., арк. 38; К., Изъ Снятинщины пишуть намъ ... [From Snyatyn region write to us], in «Дьло», 1901, 21 лютого (6 марта), ч. 41, с. 3.

33 Очевидець, Зъ Городенки. (Аматорске представленє) [From Corodenka. (Amateur presentation)], in «Дьло», 1901, 12 (25) марта, ч. 57, с. 2.

34 Читальня «Просьвіти» в Снятинї розвиває ся дуже гарно ... [Reading room of «Prosvita» in the town of Snyatyn is developing very well], in «Свобода. Політичне, просьвітне і господарске письмо для народу», 1901, 15 (28) лютого, ч. 7, с. 2.

35 Изъ Снятина пишуть намъ ... [From the town of Snyatyn to write], in «Дьло», 1900, 14 (27) грудня, ч. 280 , с. 2-3; К., Изъ Снятинщины пишуть намъ ..., с. 3.

36 ЦДІАЛ України, ф. 348, оп. 1, спр. 5131 Протоколи зборів, списки, звіти та інші документи про діяльність читальні в Снятині-місто. 1898-1939 рр., арк. 39.

37 ЦДІАЛ України, ф. 348, оп. 1, спр. 5120 Листування з філіалом в Снятині про заснування нових читалень, проведення загальних зборів, сплату членських внесків та інші організаційні питання. 1909-1926 рр., арк. 5, 10.

38 ЦДІАЛ України, ф. 348, оп. 1, спр. 5122 Звіти про діяльність філіалу в Снятині. 1909-1938 рр., арк. 5.

39 ЦДІАЛ України, ф. 348, оп. 1, спр. 5120 Листування з філіалом в Снятині про заснування нових читалень, проведення загальних зборів, сплату членських внесків та інші організаційні питання. 1909-1926 рр., арк. 7.

40 ЦДІАЛ України, ф. 348, оп. 1, спр. 5120 Листування з філіалом в Снятині про заснування нових читалень, проведення загальних зборів, сплату членських внесків та інші організаційні питання. 1909-1926 рр., арк. 9.

41 ЦДІАЛ України, ф. 348, оп. 1, спр. 5120 Листування з філіалом в Снятині про заснування нових читалень, проведення загальних зборів, сплату членських внесків та інші організаційні питання. 1909-1926 рр., арк. 12-15.

42 ЦДІАЛ України, ф. 348, оп. 1, спр. 5120 Листування з філіалом в Снятині про заснування нових читалень, проведення загальних зборів, сплату членських внесків та інші організаційні питання. 1909-1926 рр., арк. 28.

43 ЦДІАЛ України, ф. 348, оп. 1, спр. 5120 Листування з філіалом в Снятині про заснування нових читалень, проведення загальних зборів, сплату членських внесків та інші організаційні питання. 1909-1926 рр., арк. 28; спр. 5122 Звіти про діяльність філіалу в Снятині. 1909-1938 рр., арк. 1.

44 ЦДІАЛ України, ф. 348, оп. 1, спр. 5122 Звіти про діяльність філіалу в Снятині. 1909-1938 рр., арк. 1 зв.

45 ЦДІАЛ України, ф. 348, оп. 1, спр. 5118 Матеріали про діяльність філіалу товариства в містечку Снятин та репресії з боку окупаційних органів (Статистичні відомості, інформації, розпорядження і інші). 1909-1938 рр., арк. 1, 8.

46 ЦДІАЛ України, ф. 348, оп. 1, спр. 5120 Листування з філіалом в Снятині про заснування нових читалень, проведення загальних зборів, сплату членських внесків та інші організаційні питання. 1909-1926 рр., арк. 28; спр. 5122 Звіти про діяльність філіалу в Снятині. 1909-1938 рр., арк. 37. 
47 ЦДІАЛ України, ф. 348, оп. 1, спр. 5119 Протоколи зборів і засідань членів філіалу в Снятині (оригінали і копії). 1909-1938 рр., арк. 22.

48 ЦДІАЛ України, ф. 348, оп. 1, спр. 5119 Протоколи зборів і засідань членів філіалу в Снятині (оригінали і копії). 1909-1938 рр., арк. 8.

49 ЦДІАЛ України, ф. 348, оп. 1, спр. 5119 Протоколи зборів і засідань членів філіалу в Снятині (оригінали і копії). 1909-1938 рр., арк. 23; спр. 5120 Листування з філіалом в Снятині про заснування нових читалень, проведення загальних зборів, сплату членських внесків та інші організаційні питання. 1909-1926 рр., арк. 85,88 .

50 ЦДІАЛ України, ф. 348, оп. 1, спр. 5119 Протоколи зборів і засідань членів філіалу в Снятині (оригінали і копіi). 1909-1938 рр., арк. 8, 9.

51 ЦДІАЛ України, ф. 348, оп. 1, спр. 5119 Протоколи зборів і засідань членів філіалу в Снятині (оригінали і копіï). 1909-1938 рр., арк. 18.

52 ЦДІАЛ України, ф. 348, оп. 1, спр. 5119 Протоколи зборів і засідань членів філіалу в Снятині (оригінали і копії). 1909-1938 рр., арк. 9.

53 ЦДІАЛ України, ф. 348, оп. 1, спр. 5119 Протоколи зборів і засідань членів філіалу в Снятині (оригінали і копіï). 1909-1938 рр., арк. 18 зв.

54 ЦДІАЛ України, ф. 348, оп. 1, спр. 5119 Протоколи зборів і засідань членів філіалу в Снятині (оригінали і копіï). 1909-1938 рр., арк. 21 зв.

55 ЦДІАЛ України, ф. 348, оп. 1, спр. 5119 Протоколи зборів і засідань членів філіалу в Снятині (оригінали і копії). 1909-1938 рр., арк. 31.

56 ЦДІАЛ України, ф. 348, оп. 1, спр. 5119 Протоколи зборів і засідань членів філіалу в Снятині (оригінали і копії). 1909-1938 рр., арк. 9.

57 ЦДІАЛ України, ф. 348, оп. 1, спр. 5119 Протоколи зборів і засідань членів філіалу в Снятині (оригінали і копії). 1909-1938 рр., арк. 10.

58 ЦДІАЛ України, ф. 348, оп. 1, спр. 5119 Протоколи зборів і засідань членів філіалу в Снятині (оригінали і копії). 1909-1938 рр., арк. 10-11.

59 ЦДІАЛ України, ф. 348, оп. 1, спр. 5119 Протоколи зборів $і$ засідань членів філіалу в Снятині (оригінали і копії). 1909-1938 рр., арк. 37; спр. 5120 Листування з філіалом в Снятині про заснування нових читалень, проведення загальних зборів, сплату членських внесків та інші організаційні питання. 1909-1926 рр., арк. 93-97.

60 ЦДІАЛ України, ф. 348, оп. 1, спр. 5119 Протоколи зборів і засідань членів філіалу в Снятині (оригінали і копії). 1909-1938 рр., арк. 37 зв.; спр. 5122 Звіти про діяльність філіалу в Снятині. 1909-1938 рр., арк. 10.

61 ЦДІАЛ України, ф. 348, оп. 1, спр. 5119 Протоколи зборів і засідань членів філіалу в Снятині (оригінали і копії). 1909-1938 рр., арк. 11.

62 ЦДІАЛ України, ф. 348, оп. 1, спр. 5119 Протоколи зборів і засідань членів філіалу в Снятині (оригінали і копї). 1909-1938 рр., арк. 7.

63 ЦДІАЛ України, ф. 348, оп. 1, спр. 5119 Протоколи зборів і засідань членів філіалу в Снятині (оригінали і копії). 1909-1938 рр., арк. 34.

64 ЦДІАЛ України, ф. 348, оп. 1, спр. 5119 Протоколи зборів і засідань членів філіалу в Снятині (оригінали і копіï). 1909-1938 рр., арк. 21.

65 ЦДІАЛ України, ф. 348, оп. 1, спр. 5120 Листування з філіалом в Снятині про заснування нових читалень, проведення загальних зборів, сплату членських внесків та інші організаційні питання. 1909-1926 рр., арк. 60.

66 ЦДІАЛ України, ф. 348, оп. 1, спр. 5119 Протоколи зборів і засідань членів філіалу в Снятині (оригінали і копіi). 1909-1938 рр., арк. 43, 44, 44 зв.

67 ЦДІАЛ України, ф. 348, оп. 1, спр. 5119 Протоколи зборів і засідань членів філіалу в Снятині (оригінали і копії). 1909-1938 рр., арк. 45.

68 ЦДІАЛ України, ф. 348, оп. 1, спр. 5119 Протоколи зборів і засідань членів філіалу в Снятині (оригінали і копії). 1909-1938 рр., арк. 48.

69 Выдъловый, Въ снятиньскомъ повъть [In Snyatyn county], in «Свобода. Письмо політичне, просвђтне и господарске для народу», 1899, 15 (27) цвђтня, ч. 16, с. 126.

70 Зі Снятина. Перші загальні збори снятинської філії «Просьвіти» відбули ся ... [From Snyatyn. The first general meeting of the Snyatyn affiliate took place], in «Дїло», 1909, 29 (16) вересня, ч. 213 , с. 4.

71 ЦДІАЛ України, ф. 348, оп. 1, спр. 5119 Протоколи зборів $і$ засідань членів філіалу в Снятині (оригінали і копії). 1909-1938 рр., арк. 18, 18 зв., 19, 19 зв.; спр. 5120 Листування з філіалом в Снятині про заснування нових читалень, проведення загальних зборів, сплату членських внесків та інші організаційні питання. 1909-1926 pp., арк. 75. 
72 ЦДІАЛ України, ф. 348, оп. 1, спр. 5119 Протоколи зборів і засідань членів філіалу в Снятині (оригінали і копї). 1909-1938 рр., арк. 25-29.

73 Часть інформацийна. Провідник по Галичинї [Information part. Guidebook to Galicia], in «Ілюстрований калєндар товариства «Просьвіта» на рік звичайний 1910», Львів, 1910, річник XXXIII, с. 32.

\section{References}

1. Bezstoronnyi, Z Sniatynskoho [From Snyatynsky], in «Svoboda. Pysmo politychne, prosvitne i hospodarske dlia narodu», 1899, 7 (23) sichnia, ch. 3, s. 20.

2. Chast informatsyina. Providnyk po Halychyni [Information part. Guidebook to Galicia], in «Iliustrovanyi kaliendar tovarystva «Prosvita» na rik zvychainyi 1910», Lviv, 1910, richnyk XXXIII, s. 32.

3. Chytalnia «Prosvity» v Sniatyni rozvyvaie sia duzhe harno ... [Reading room of «Prosvita» in the town of Snyatyn is developing very well], in «Svoboda. Politychne, prosvitne i hospodarske pysmo dlia narodu», 1901, 15 (28) liutoho, ch. 7, s. 2.

4. Dalshe sviatkovanie narodnoho yuvyleiu. V sniatynskim poviti [Celebrating people's anniversary. In Sniatyn county], in «Svoboda. Pysmo politychne, prosvbtne y hospodarske dlia narodu», 1898, 21 maia (2 chervnia), ch. 21, s. 164.

5. Dnia 9 liutoho s. r. vidbuly sia v Sniatyni vechernytsi v chest Tarasa Shevchenka ustroieni tovarystvom «Nauka» ... [A celebratory evening in honor of Taras Shevchenko took place in Snyatyn on February 9, organized by the society «Science»], in «Dilo», 1896, 19 liutoho (2 marta), ch. 38, s. 3.

6. Filiy y chytalni «Prosvity» [Affiliates and reading rooms of «Prosvita»], in «Dilo», 1897, 5 (17) lypnia, ch. 150, S. 3.

7. Iz Sniatyna pyshut nam ... [From the town of Snyatyn to write], in «Dilo», 1900, 14 (27) hrudnia, ch. 280, s. 2-3; K., Iz Sniatynshchyny pyshut nam ..., s. 3.

8. K., Iz Sniatynshchyny pyshut nam ... [From Snyatyn region write to us], in «Dilo», 1901, 21 liutoho (6 marta), ch. 41, s. 3.

9. A. Korolko, Diialnist oseredkiv tovarystva «Prosvita» na Pokutti naprykintsi KhIKh - pochatku KhKh st. (za materialamy chasopysu «Dilo») [Activity of cells of «Prosvita» in Pokuttia at the late XIXth - early XXth centuries (based on «Dilo» newspaper)], in «Pokuttia - kolyska ukrainskoho natsionalnoho derzhavotvorennia», Ivano-Frankivsk, 2018, s. 237-266.

10. A. Korolko, «Kolomyiske tovarystvo Narodnykh Spilok»: ideolohichni zasady i praktychna diialnist yii oseredkiv na Pokutti (kinets XIX - pochatok XX st.) [«Kolomyia society of People’s Unions»: ideological principles and practice of its branches in Pokuttia (late XIXth - early XXth centuries)], in «Pytannia istorii Ukrainy», Chernivtsi, Tekhnodruk, 2014, t. 17, s. 68-82.

11. A. Korolko, «Narodni spilky» na Sniatynshchyni v kintsi XIX - na pochatku XX st. [«People’s Unions» in Snyatyn region (late XIXth - early XXth centuries)], in «Sniatyn. Kraieznavchyi i literaturno-mystetskyi zhurnal», 2016, ch. 15(29), s. 62-77.

12. A. Korolko, Statuty «Prosvity» - holovnyi chynnyk orhanizatsii diialnosti filii i chytalen ukrainskykh kulturnoprosvitnikh tovarystv v Halychyni (ostannia tretyna XIX - pochatok XX st.) [Statues of «Prosvita» - the main factor in organizing the activties of affiliates and reading rooms of Ukrainian cultural and associations in Galicia (last third XIXth - early XXth centuries)], in «Kaluski istorychni studii», t. 3. Zbirnyk naukovykh statei, dokumentiv i materialiv, prysviachenyi 150-richchiu stvorennia tovarystva «Prosvita, Ivano-Frankivsk, 2019, s. 29-41.

13. K. [yrylo] T. [rylovskyi], Z Sniatynskoho [From Snyatynsky], in «Svoboda. Pysmo politychne, prosvitne i hospodarske dlia narodu», 1898, 4 serpnia (23 lypnia), ch. 30, s. 238.

14. Novyi statut Tovarystva «Prosvita» [The new charter of «Prosvita»], in «Batkivshchyna», 1891, 22 marta (3 tsvitnia), ch. 12, s. 72.

15. Ochevydets, $\mathrm{Z}$ Horodenky. (Amatorske predstavlenie) [From Corodenka. (Amateur presentation)], in «Dilo», 1901, 12 (25) marta, ch. 57, s. 2.

16. Pershii ustav dlia Chytalen «Prosvity» ukhvalenyi Holovnym Vydilom tovarystva «Prosvita» u Lvovi dnia 24 n. st. sichnia $1894 \mathrm{r}$. [The first charter for reading rooms of «Prosvita» of the approved by the headquarters in Lviv of January 24, 1894], in «Dilo», 1894, 19 (31) sichnia, ch. 14, s. 1-2.

17. Reguliamin i instruktsyia dlia vydilu filii «Prosvity» [Rules and instructions for affiliate management of «Prosvita»], in «Dilo», 1908, 5 chervnia (23 maia), s. 124, s. 2-3.

18. A. Serediak, Diialnist tovarystva «Prosvita» v 1868-1914 rr. [The activities of «Prosvita» in 1868-1914], in «Narys istorii "Prosvity”», Krakiv, Paryzh, Lviv, 1993, s. 18-42.

19. Sorok lit diialnosty «Prosvity» [Forty years of activity of the «Prosvita»], in «Dilo», 1908, 8 hrudnia (25 padolysta), ch. 276, s. 1-2. 
20. Spravozdanie Narodnoho Komitetu. (Dalshe) [Report of the Peoples Committee (Continuation)], in «Dilo», 1900, 7 (20) lypnia, ch. 151, s. 2.

21. Spravozdanie Tovarystva «Prosvita» z rukhu prosvitno-ekonomichnoho v r. 1896. Liustratsiy Chytalen «Prosvity» y hospodarskykh selianskykh [Report of «Prosvita» on the educational and economic movement in 1896. Lustration reading rooms of «Prosvita» and peasant farms], in «Svoboda. Pysmo politychne, prosvitne i hospodarske dlia narodu», 1897, 13 (25) marta, ch. 11, s. 85.

22. Spravozdanie z liustratsiy chytalen y hospodarstv selianskykh, perevedenoy liustratorom «Prosvity» v poviti sniatynskim [v chas vid 20 veresnia do 4 zhovtnia 1896] [Report from of the lustration of the readings and peasant farms in Snyatyn County (September 20 - October, 1896)], in «Dilo», 1896, 11 (23) hrudnia, ch. 277 , s. 1 .

23. Tsentralnyi derzhavnyi istorychnyi arkhiv Ukrainy, m. Lviv (dali - TsDIAL Ukrainy), f. 348 Tovarystvo «Prosvita», m. Lviv, op. 1, spr. 5118 Materialy pro diialnist filialu tovarystva v mistechku Sniatyn ta represii z boku okupatsiinykh orhaniv (Statystychni vidomosti, informatsii, rozporiadzhennia i inshi). 1909-1938 rr., 9 ark.

24. TsDIAL Ukrainy, f. 348, op. 1, spr. 5119 Protokoly zboriv i zasidan chleniv filialu v Sniatyni (oryhinaly i kopii). 1909-1938 rr., 296 ark.

25. TsDIAL Ukrainy, f. 348, op. 1, spr. 5120 Lystuvannia z filialom v Sniatyni pro zasnuvannia novykh chytalen, provedennia zahalnykh zboriv, splatu chlenskykh vneskiv ta inshi orhanizatsiini pytannia. 1909-1926 rr., 248 ark.

26. TsDIAL Ukrainy, f. 348, op. 1, spr. 5122 Zvity pro diialnist filialu v Sniatyni. 1909-1938 rr., 92 ark.; f. 348, op. 1, spr. 5131 Protokoly zboriv, spysky, zvity ta inshi dokumenty pro diialnist chytalni v Sniatyni-misto. 1898-1939 rr., 134 ark.

27. TsDIAL Ukrainy, f. 348, op. 1, spr. 5131 Protokoly zboriv, spysky, zvity ta inshi dokumenty pro diialnist chytalni v Sniatyni-misto. 1898-1939 rr., 39 ark.

28. Vechernytsi bez publyky. Z Sniatyna pyshut nam ... [Festiv evening without public. Write to us from the town of Snyatyn], in «Dilo», 1897, 8 (20) serpnia, ch. 178, s. 1.

29. Vychosa. Z Sniatyna pyshut nam ... [Vychosa. Write to us from the town of Snyatyn], in «Dilo», 1898,11 (23) maia, ch. 103, s. 2.

30. Vydilovyi, V sniatynskim poviti [In Snyatyn county], «Svoboda. Pysmo politychne, prosvitne i hospodarske dlia narodu», 1899, 15 (27) tsvitnia, ch. 16, s. 126.

31. Yuvylei znesenia panshchynы y narodnoho vôdrodzhenia halytskoy Rusy [Anniversary of the abolition of bonhold and the national revival of Galician Rus], in «Svoboda. Pysmo politychne, prosvitne i hospodarske dlia narodu», 1898, 7 (19) maia, ch. 19, s. 149.

32. Zahalni Zbory tovar. Prosvita. (Konets) [General meeting of «Prosvita». (The end)], in «Dilo», 1890, 13 (25) serpnia, ch. 182, s. 1.

33. Zakladaite «Narodni Spilky»! [Establish «People's Unions»!], in «Zaporozhets. Kaliendar na perestupnyi rik 1904», Kolomyia, 1904, s. 115.

34. Zi Sniatyna. Pershi zahalni zbory sniatynskoi filii «Prosvity» vidbuly sia ... [From Snyatyn. The first general meeting of the Snyatyn affiliate took place], in «Dilo», 1909, 29 (16) veresnia, ch. 213, s. 4.

35. Zô Sniatyna pyshut nam ... [From the town of Snyatyn to write], in «Dilo», 1898, 30 zhovtnia (11 padolysta), s. 2.

36. Z Sniatyna pyshut nam: Dnia $27 \mathrm{n}$. st. zhovtnia vidbuly sia v Sniatyni pershi zahalni zbory povbtovoho tovarystva «Nauka» [From the town of Snyatyn to write: The first general meeting of the county society «Science» took place in Snyatyn on October 27], in «Dilo», 23 zhovtnia (4 padolysta), ch. 238, s. 3.

37. Z Sniatyna pyshut nam: «Nasha duma, nasha pisnia ne vmre, ne zahyne, y ozhyve dobra slava, slava Ukrainy» ... [From the town of Snyatyn to write: «Our word, our song, will not die, will not perish, and the good, glory of Ukraine will come to life»], in «Dilo», 1896, 10 (22) serpnia, ch. 179, s. 3.

38. I. Zuliak, Rol «Prosvity» u poshyrenni ekonomichnykh znan u Skhidnii Halychyni (kinets XIX - pochatok XX st.) [The role of «Prosvita» in disseminating economic knowledge in Eastern Galicia (late XIXth - early XXth centuries)], in «Ukraina: kulturna spadshchyna, natsionalna svidomist, derzhavnist», Lviv, 2010, vyp. 19, s. $151-160$. 